This item was submitted to Loughborough's Research Repository by the author.

Items in Figshare are protected by copyright, with all rights reserved, unless otherwise indicated.

\title{
Human capital and conflict management in the entrepreneur-venture capitalist relationship: the entrepreneurs' perspective
}

\section{PLEASE CITE THE PUBLISHED VERSION}

\section{PUBLISHER}

Palgrave Macmillan / @ Authors

\section{VERSION}

AM (Accepted Manuscript)

\section{PUBLISHER STATEMENT}

This work is made available according to the conditions of the Creative Commons Attribution-NonCommercialNoDerivatives 4.0 International (CC BY-NC-ND 4.0) licence. Full details of this licence are available at: https://creativecommons.org/licenses/by-nc-nd/4.0/

\section{LICENCE}

CC BY-NC-ND 4.0

\section{REPOSITORY RECORD}

Zou, Huan, Grahame Boocock, and Xiaohui Liu. 2019. "Human Capital and Conflict Management in the Entrepreneur-venture Capitalist Relationship: The Entrepreneurs' Perspective”. figshare.

https://hdl.handle.net/2134/17327. 


\title{
Human Capital and Conflict Management in the Entrepreneur-Venture Capitalist Relationship: The Entrepreneurs’ Perspective
}

\author{
Huan Zou \\ Department of Financial and Management Studies \\ School of Oriental and African Studies, University of London \\ Thornhaugh Street, Russell Square \\ London WC1H 0XG \\ U.K. \\ Email: h.zou@soas.ac.uk
}

Grahame Boocock

School of Business and Economics

Loughborough University, Leicestershire LE11 3TU

U.K.

Email: j.g.boocock@lboro.ac.uk

Xiaohui Liu

School of Business and Economics

Loughborough University, Leicestershire LE11 3TU

U.K.

Email: x.liu2@lboro.ac.uk (corresponding author) 


\title{
Human Capital and Conflict Management in the Entrepreneur-Venture Capitalist Relationship: The Entrepreneurs' Perspective
}

\begin{abstract}
Entrepreneurs' human capital is important in the entrepreneur-venture capitalist (E-VC) relationship where conflict between the two parties is almost inevitable. However, how human capital affects entrepreneurs' responses to conflict is under explored. Adopting a qualitative analysis, this study integrates the human capital and conflict management literature to examine the factors that cause conflict in the E-VC relationship in China and to investigate how entrepreneurs with different degrees of human capital respond to conflict. Our findings show communication barriers, and different goals and value systems are the main sources of conflict between Chinese entrepreneurs and foreign VCs. Entrepreneurs with start-up experience are more likely to adopt collaborative and competing strategies and hence have a more positive and productive attitude towards conflict with VCs, whereas inexperienced entrepreneurs tend to use passive accommodating and avoiding approaches that create problems in the E-VC relationship.
\end{abstract}




\section{Human Capital and Conflict Management in the Entrepreneur-Venture Capitalist Relationship: The Entrepreneurs' Perspective}

\section{INTRODUCTION}

Modern venture capital is recognized as an important catalyst for fostering entrepreneurship, innovation and economic growth, especially in emerging economies (Lerner, 1999). Venture capital firms seek to support enterprises that progress within a relatively short space of time from start-ups or small beginnings to high growth firms ( Shane, 2008). Value-adding activities by venture capitalists (VCs) can result in higher survival rates for investee firms compared to similar 'non-venture capital' ventures (Arthurs and Busenitz, 2006). Yet, the input of VCs does not always result in positive outcomes (Zacharakis and Meyer, 2000), and failure or weak performance in investee firms is frequently explained by conflict in the entrepreneur-venture capitalist (E-VC) relationship (Higashide and Birley, 2002; Yitshaki, 2008). Indeed, conflict is almost unavoidable in a relationship often defined by control rather than trust (Das and Teng, 2001) and where power asymmetry typically favours the investors (Pfeffer and Salancik, 2003). The root of much conflict is a failure to agree on the goals to be achieved by an investee firm or the strategy to be adopted in pursuit of those goals (Jehn and Mannix, 2001).

Although there is growing academic interest in the development of venture capital industries in emerging economies (Ahlstrom, Bruton and Yeh, 2007), the majority of these studies have been conducted from the perspective of VCs; very few studies have taken into account the views of entrepreneurs or CEOs in venture capital-backed firms (Ehrlich, et al., 1994; Yitshaki, 2008). The causes and consequences of conflict still require greater academic 
scrutiny, (Manigart and Sapienza, 2000; Zacharakis et al., 2010), and we view the role of entrepreneurs' human capital as critical in this context. If entrepreneurs and VCs can build a productive relationship based on mutual respect and trust, this should enhance a portfolio firm's prospects of survival and/or success and, at the same time, increase the chance of a healthy return for the venture capital fund.

Conflict resolution thus benefits investee firms and their backers, and generates wealth in the wider economy. Specifically, we contend that the human capital of entrepreneurs gives them the capacity to face the challenges of developing their firms under VCs' supervision. However, our knowledge of the interaction between human capital and conflict management is limited. To address this gap in the existing literature, we focus on two research questions:

1. What are the sources of conflict in the E-VC relationship, with particular reference to cultural factors?

2. How does the human capital of entrepreneurs affect their responses to managing conflict with VCs, especially foreign VCs?

China represents an interesting research setting. Its venture capital industry has been one of the fastest growing in the global venture capital market (Ahlstrom et al., 2007). Foreign VCs have played an increasingly important role in financing domestic new ventures, particularly in the high-technology sphere; foreign venture capital firms funded over 52 per cent of venture capital investments by number in China in 2010, representing 71 per cent of venture capital investment by value (Cai and Song, 2010). Our empirical research was conducted in Beijing and Shanghai, cities where large numbers of new ventures have been financed by venture capital (Cai and Song, 2010). Yet, this form of capital (whether from domestic or foreign sources) remains in short supply for many Chinese firms, and its impact on investee firms is 
under explored (Xiao, 2011). It is therefore imperative that firms in receipt of venture capital are able to respond appropriately to conflict in the E-VC relationship.

This chapter makes a number of contributions to the literature. First, it adds a new dimension to existing studies by investigating how the human capital of entrepreneurs leads to the adoption of different strategies in the management of conflict with VCs. Second, our analysis is based upon in-depth interviews with nine entrepreneurs in receipt of venture capital funding hence it complements previous studies conducted from the perspective of VCs; we offer new insights into how conflict stems from different cultural contexts of entrepreneurs and also their differing characteristics. Third, we put forward a series of propositions that enhance our understanding of the complexity of the E-VC relationship. Finally, our findings have important implications for all those seeking to maximize the positive impact of venture capital on entrepreneurial ventures.

\section{THEORETICAL FOUNDATIONS}

\section{Conflict: Sources and Resolution}

Conflict refers to a situation where the parties in a relationship are aware of, yet still seek to occupy, a position that is incompatible or irreconcilable with the wishes of others (Boulding, 1963; Jehn and Mannix, 2001). As stated earlier, conflict is almost unavoidable in the E-VC relationship (Higashide and Birley, 2002), commonly linked to a failure to agree on goals or the strategy to secure those goals (Jehn and Mannix, 2001; Zacharakis et al., 2010). However, Yitshaki (2008) argues that conflict in VC provision stems from three broad (and interlinked) sources: ‘contractual' - covering a whole range of perceived contract violations, not just 
disputes over the best way to secure the goals laid down in the term sheet but also disagreements on the support provided by a venture fund, the imposition of a new management team, the timing of any VC exit, and so on (Parhankangas and Landström, 2004); 'contextual' - usually stemming from differences in perception over the competitive environment facing the investee firm or the firm's level of performance; and 'procedural' largely relating to communication issues.

The role of different cultural contexts in creating conflict has been emphasised in both the general literature in this field (Tjsovold, Law and Sun, 2006) and also in VC-focused studies (Yitshaki, 2008). Cultural diversities can lead to procedural conflict between Chinese entrepreneurs and foreign VCs, for example, as Western VCs tend to concentrate on building relationships with the CEO, whereas their Chinese counterparts also maintain contact with senior and middle-ranked managers (Pukthuanthong and Walker, 2007). At the strategic level, contractual conflict might ensue in cases where indigenous entrepreneurs resent the imposition of short-term targets by western VCs, rather than the longer-term, collectivist approach favoured by their Asian counterparts (Wright et al., 2005).

The literature in conflict management has proposed four approaches to resolving conflict collaborating, competing, accommodating and avoiding (Deutsch, 1973; Thomas, 1976). The collaborative approach implies that one party attempts to work with the other in an effort to find a mutually acceptable solution; it requires the parties in conflict to be open, to share information and to be aware of their differences (Wang, Jing, and Klossek, 2007). This strategy creates shared understanding, and it usually results in positive and constructive outcomes (Yitshaki, 2008). The competing approach is employed when one party is resolute in what s/he believes and wants. This strategy implies that one party holds a position of power, expertise or strength and thus a high level of assertiveness; the needs and expectations of the other party are sometimes ignored (Rahim, 2002). The accommodating approach occurs 
where one party makes sacrifices to satisfy the requirements of the other; again, this may reflect a power-based relationship. Finally, the avoiding approach attempts to smooth over conflicts and minimize discussion of them (Chen, et al., 2005); this may involve turning away from conflict or even refusing to acknowledge its existence.

\section{Human Capital}

Human capital gives entrepreneurs a reservoir of skills, knowledge and abilities to draw upon as they face ongoing challenges (Cooper, Estes and Allen, 2004; Keong and Mei, 2010).

Despite its importance, research on the relationship between human capital and conflict management has been limited (De Vries and Shields, 2006; Envick, 2005), especially in the E-VC relationship (Wright, Low and Davidson, 2001). Moreover, scholars have concentrated largely on establishing the psychological traits required by entrepreneurs in times of conflict (Cooper and Lucas, 2006), for example: Timmons (1999) argues that successful entrepreneurs have the ability in their DNA to recover from adversity. However, we endorse the view of Morris (2002) that the sustainability of a venture depends more heavily on behavioural capabilities than psychological characteristics.

We view human capital as a spectrum of skills and knowledge with varying degrees of transferability. The acquisition of knowledge is a long-term process by which "entrepreneurs transform experience into knowledge in disparate ways” (Politis, 2005: 408). As well as his/her formal education, an entrepreneur's previous start-up experience, knowledge of the industry and market, past employment experience, and technical knowledge can affect his/her behaviour and strategic decision-making, and, ultimately, firm performance (Bruderl, Preisendorfer and Ziegler, 1992; Bosma, et al., 2004). We share the view that prior experience, education and personal background shape the perceptions and mindsets of entrepreneurs (Kor, Mahoney, and Michael, 2007), enabling them to make appropriate 
strategic responses in fast-changing external environments (Huff, 1990) or to develop early warning systems to visualize and anticipate future events (Cope, 2010).

\section{RESEARCH METHODOLOGY}

While a positivist approach has dominated in entrepreneurship research, it is acknowledged (McDougall and Oviatt, 2000) that this stance may not have generated meaningful causal laws or principles in the context of entrepreneurial activities such as opportunity recognition or value creation - key goals of venture capital-backed firms (Shane, 2008). Coviello and Jones (2004) called for a more interpretive perspective. Our study answers this call. Drawing on the literature from the fields of conflict management and human capital, we utilised a number of in-depth case studies to examine how the characteristics of entrepreneurs affect their attitude and approach towards conflict, and also their strategic responses to the resolution of conflict. Following established procedures for inductive research (Glaser, 1978; Miles and Huberman, 1994), we captured situated insights into the interaction of entrepreneurs and VCs, as well as rich details and thematic descriptions of the E-VC relationship.

\section{Sample Selection}

A common feature of interpretive studies is the use of small samples, yet a competent theoretical perspective can be developed as long as adequate contextualization is preserved (Chapman and Smith, 2002). Researchers have to be pragmatic in choosing participants (Reid, Flowers and Larkin 2005), particularly where the topic under investigation is rare, and issues of accessibility and willingness to participate are problematic (as was the case here). 
We used the Thomson Financial Private Equity/Venture Capital Dataset to identify high-tech firms in China that had received VC investment. We emailed the research proposal to 200 firms, but only five firms indicated a willingness to participate. The very low response rate was not unexpected, mainly because of a reluctance to talk openly about conflict with VC investors. Nonetheless, five cases constituted an acceptable number for the initial round of interviews; the data were collected and analysed almost simultaneously, and it was evident that it was necessary to gather more data. We asked the initial interviewees to recommend other firms that had received VC investment. This snowball or chain sampling strategy (Hartley, 1994) secured an additional four participants. We called a halt to the interview programme only when we were satisfied that sufficient data had been collected on each of the issues of relevance to our research questions.

In total, nine interviews were completed with entrepreneurs representing venture capitalbacked firms in Beijing and Shanghai. Table 1 provides an anonymised profile of the participants, as well as basic information on the firms and their venture capital investors. Table 2 captures the previous experience of the interviewees and summarizes the networks available to them.

\section{ニニニニニニニニニニニニニニニニニニニニニ}

INSERT TABLES 1 and 2 HERE

\section{FINDINGS}

\section{Sources of Conflict in the E-VC Relationship}


We classify our findings by reference to Yitshaki’s (2008) three sources of conflict (contractual; contextual; and procedural), although the boundaries between these categories are somewhat blurred. Quotes from the interview transcripts are used sparingly, to emphasize key issues or common themes.

\section{Contractual conflict}

This type of conflict emanated from disputes over the goals to be pursued by investee firms or the level of support provided by VCs. The analysis below shows that some of our sample firms avoided this type of conflict, whereas other firms had very different experiences. In Firms $H$ and $R$, both funded by Japanese and domestic VCs, there was a mutual acceptance of the goals to be pursued; for example, the CEO of Firm H stressed that: "We [entrepreneur and VC Fund] take decisions that achieve reliable and sustainable operations. The VCs have to immerse themselves in the firm for the long haul; they could not succeed if they just wanted to gamble and pursue short-term interests.” On similar lines, Firm D held fruitful discussions with its VC-backer (the Asian arm of the venture capital unit formed by IDG - a global data company), to secure future growth by moving from a funding structure appropriate for angel investors into one which complied with NASDAQ listing requirements. This level of agreement was not present in Firms K, E and Y. Firms K and E were funded partly or wholly by US VC Funds, whereas Firm $Y$ was backed by domestic venture capital. The CTO of Firm K pointed to fundamental differences in outlook ("We stood on different planets"), sentiments that were echoed by the CEO of Firm E (“These guys [VCs] do not position themselves as value-added investors”) and the Deputy General Manager (DGM) in Firm $Y$ (“... We have tried to meet the investors’ short-term targets even though we knew that this would damage our long-term objectives”). 
In relation to the support provided, Firm $R$ applauded its Japanese investors for promising (and then delivering) introductions to potential customers and suppliers, while Firm D praised its VCs for playing to the strengths of both parties: "We are technically-proficient in the internet industry, but IDG have much greater expertise on commercial issues.” By contrast, Firms $K, E$ and $Y$ were disappointed with the support offered by their VCs, for example: the CEO of Firm E complained about the investors' failure to provide contacts: “companies that we might acquire or who might partner with us”. .

Firms $H, R, N$ and $D$ could agree on the goals to be pursued with their VC backers, whereas Firms $K$, E and $Y$ could not. There was a similar split of opinion concerning VCs's support. These outcomes cannot be explained solely by 'East versus West' disputes, as Firm D dealt with the local arm of a US-based VC group while Firm $Y$ was funded by a domestic venture capital. However, it was noticeable that first-time entrepreneurs ( $K, E$ and $Y$ ) tended to be involved in contractual conflict; Firm D was an exception - inexperienced entrepreneurs acknowledged the superior skills that the VCs could supply.

\section{Contextual conflict}

At the root of contextual conflict are differences in perceptions, attitudes and values between entrepreneurs and VCs (Yitshaki 2008). The impact of cultural differences was also a major factor under this heading. Contextual conflict was averted in cases where the firm and its VC investors shared the same time perspective or business orientation. For example, the CFO of Firm $R$ conceded that he and his colleagues sometimes wanted to grasp opportunities immediately, whereas their Japanese investors might take a more cautious line: “[Yet, overall] ... our VCs respect our experience and judgment, and we are lucky to have investors who are quite patient in relation to firm growth. The growth demands of US investors would have had 
a serious impact on the confidence of our top management team.” Likewise in Firm H: “Our Japanese investors share similar ideas and philosophies with us, and they do not push us aggressively in a certain direction.”

These positive views can be contrasted with a range of complaints from other interviewees. In Firm K, for instance, US VCs challenged the entrepreneurs on both operational issues and corporate strategies: “The investors kept telling us how much profit we should generate, what we should do daily, what business model we should follow etc. To be honest, I am not happy with that.” In Firm Y, the management team was prepared initially to work with the investors but this situation deteriorated rapidly: "We accept that the investor can give advice on strategies, such as the R\&D to be undertaken, yet it is down to us to manage the company.” Disputes also arose when the entrepreneurs believed that VC appointees were not familiar with the Chinese environment; Firm E complained that: “[a female American-Chinese board member] was supposed to guide us, but all her suggestions ended up as being irrelevant or inappropriate for the local market.”

Procedural conflict

In relation to procedural issues, various aspects of communication created difficulties for investee firms, but we also found several instances of positive interaction in the E-VC relationship. By way of illustration, Firm $H$ stressed that “communication is critical”, and explained how the founder built up trust with investors by establishing monthly, face-to-face meetings, backed up by email or phone contact in the interim. Similarly, the CEO of Firm V stated that informal contacts with VCs beforehand ensure that: “... board meetings are productive and efficient in delivering decisions”. 
The experiences of Firms $E$ and $D$ in communicating with their US investors were very different. Firm E viewed the VCs' contribution as lacking empathy, and communications with investors were seen as a burden rather than a support mechanism. The CEO of Firm D stated that the two IDG board members (both overseas Chinese) commute regularly between different continents hence: “... the VC appointees have too many projects, and they have limited time to take care of us or to communicate frequently with us.” Such problems were not confined to US venture capitalists, as the experience of Firm Y illustrates. Contractual agreements with its domestic VC Fund were not supported by procedural guidelines; this created a situation of uncertainty and potential future conflict.

The experiences of five entrepreneurs (Firms $I, V, R, H$ and $N$ ) were broadly positive in communicating with their investors. The other four participants (Firms $K, E, D$ and $Y$ ) had all experienced communication problems or other procedural disputes, for example: $K$ and $E$ had severe difficulties in communicating with their US VCs, even though both firms had secured second-round VC funding, and Firm D felt that the investors did not provide enough dedicated local support. The range of discord cited by study participants suggests that communication problems are often associated with other, deep-rooted sources of conflict.

\section{Conflict Resolution - the Role of Human Capital}

In the 'contractual' category, the human capital of the CEO in Firm H enabled him not only to obtain VC funding, but also to secure a long-term collaboration that enabled this firm to thrive in a very competitive market (Internet 3D). In this (and other) instances, the entrepreneurs' stock of human capital had enabled them to anticipate and thus prevent conflict. Positive intentions to establish the motivations of VC investors and to explore collaboration and/or compromise had improved the quality of decision making and generated benefits for all 
parties. By contrast, contractual conflict was prevalent when such flexibility and adaptability was absent, notably in Firms K and E; both firms were convinced that their VCs had consistently imposed unrealistic goals and provided inadequate support.

In relation to contextual factors, Firm $H$ stressed that communication with their Japanese VCs was not just about “procedure”, but an important mechanism for maximising the potential of the business: "We always prepare for the worst scenario then do our best to solve problems together; for instance, in the face of technical problems affecting the firm, we worked together to tackle this threat by recruiting specialist employees and seeking technology partners.” This willingness to accept help or advice, based on mutual respect, was also seen in Firm $R$. The CFO explained that the founder's experience and ability to judge market trends persuaded the VCs to allow the firm to dictate its overall growth strategy, yet the CFO admitted that VC expertise helped Firm $R$ to improve budget control and investment appraisal. The representatives of Firms $N$, I and $V$ also stressed the importance of accepting advice, albeit with limits on their willingness to accede to the demands of VCs.

Where conflict from contextual sources did arise, it usually stemmed from disagreements on the most appropriate strategy to be pursued in the face of rapidly-changing competitive environments. This was most evident in Firms $K$ and $E$ (internet-based firms) and $Y$ (robotics). The US investors in Firm K imposed their decisions on management: "We had arguments over critical strategic decisions, but they had the final call. This definitely harmed the mental state of some of the key founders; they have left or are about to leave the firm. The more the investors got involved, the more damage they did to the firm”. Likewise, the CEO of Firm E accepted that he had lost control to the VCs, and he concluded, with an air of resignation, that: "I don’t see any possibility of resolving disputes with the investors. I have officially given up, although I am still on the board” 
The first-time entrepreneurs in Firms $K$ and $E$ (and Firm $Y$ where similar issues were evident) did not have the capacity to leverage personal skills and experience to prevent or resolve conflict. They maintained a negative attitude towards the VCs and pursued a strategy of passive accommodation or outright avoidance towards conflict, and the firms' prospects were seriously compromised. However, not every first-time entrepreneur experienced contextual conflict, for example Firm D pursued a collaborative approach that maximised the complementary skills of the two parties: "We are technically very sound, but we lack an understanding of the wider business environment; [by contrast] our VCs have thorough insight into inter- and intra-industry competition, potential markets, legal issues, etc.” For procedural disputes, effective communication proved to be a powerful mechanism for resolving such conflict. A majority of sample firms $(H, I, N, R$ and $V)$ had benefited from frequent and effective exchanges of information; the examples below demonstrate how the prior experience of key individuals helped VC-backed firms to lay the foundation for sound communications and collaboration with investors.

The CEO of Firm $H$ argued that his prior entrepreneurial experience and his credibility within the VC community had been critical in forging a partnership with the firm’s Japanese investors; he had the confidence to share risks as well as opportunities with the VCs: "We know that VCs get quite concerned about technical, market and even business model risks [hence] we are very frank with them”. The CEO of Firm V also stressed the value of informal meetings and contacts with VCs in avoiding conflict and building trust; a key part of this process (also cited by Firm $H$ ) was to confront any problems quickly.

By contrast, the firms led by first-time founders had all experienced communication problems. For example, Firms $K$ and $E$ had enjoyed some degree of success but had encountered severe communication difficulties and faced an uncertain future; and the CEO of Firm $D$ felt that communication was hindered by an absence of dedicated local support. These 
cases confirm that communication problems were often associated with other sources of conflict, but we propose that a lack of experience and adaptability were the underlying reasons for procedural conflict.

The evidence indicates that, whatever the source of conflict, experienced entrepreneurs can anticipate potential challenges by adopting collaborative (and proactive) strategies that enhance trust; this trust facilitates effective communication and reduces the incidence of misunderstanding. First-time entrepreneurs lack the requisite experience and personal skills to deal with challenges and conflict in the E-VC relationship; they find it very difficult to develop a productive relationship with VCs.

\section{DISCUSSION}

In addressing our first research question, we verified that there are different sources of conflict in the E-VC relationship, yet our study extends our understanding of those sources to the Chinese (and wider) VC environment by taking cultural contexts into account. Specifically, we found that, when entrepreneurs and VCs share the same goals or when they can negotiate mutually-agreed targets, the relationship tends to be productive and healthy. In contrast, goal divergence between the two parties leads to conflict. Likewise, when entrepreneurs value the support received from their VCs, the relationship was generally sound, especially in cases where the entrepreneurs and VCs had complementary skills. When entrepreneurs perceived that VCs had not fulfilled expectations or supplied anticipated benefits, conflict was present. Some VCs were viewed as unwanted external monitors rather 
than valuable resources; there was also resentment when VCs were closely involved in the day-to-day management of firms. Hence, we propose:

Proposition 1: Goal divergence and perceived deficiencies in the support from VCs are likely to lead to contractual conflict in the E-VC relationship.

Contextual conflict in our study stemmed from differing cultural strategic orientations, and this encompassed differing attitudes towards investee firm performance. Our interviewees confirmed that Asian VCs adopt a longer-term strategic orientation (Wright et al., 2005); a number of interviewees were able to build strategic relationships on this basis. Conversely, US investors were generally perceived to pay greater attention to short-term sales and profit figures, as when Firm E complained of a "lack of empathy” from its investors and intervention in day-to-day operations that was "irrelevant or inappropriate for the local market”. In such cases, frustrated and demotivated entrepreneurs can lack the capacity to think decisively and hence fail to grasp opportunities as they arise. Therefore, we propose: Proposition 2: Differences in cultural strategic orientations and in attitudes towards business performance are likely to cause contextual conflict in the E-VC relationship.

The principal source of procedural conflict in our study was difficulties in communications between entrepreneurs and VCs (usually, but not exclusively, foreign VCs). We found that entrepreneurs who had established a close working relationship with their investors adopt a variety of communication strategies, with open discussion and frequent contacts bringing mutual, long-term benefits. Entrepreneurs in the latter category were able to create and then maintain effective communication systems with their VCs; they were also more prepared to embrace a flexible approach towards communication - to make adjustments where necessary, to admit past failings and so on. This leads to the following propositions: 


\section{Proposition 3: The failure to utilise a variety of communication mechanisms is likely to result in procedural conflict in the E-VC relationship.}

In tackling the second research question i.e. the role of human capital in responding to conflict with VCs, we found that first-time entrepreneurs, especially those with limited experience and knowledge in managing conflict with foreign VCs, tended to lack flexibility and adaptability compared to their more experienced counterparts. First-time entrepreneurs generally held negative views towards their VC investors and this led to conflict. Moreover, whatever the source of that conflict, it tended to escalate over time.

In relation to contractual conflict, the prior experience of management proved vital in aligning the goals of VCs and investee firms. In addition, when the two parties had different perceptions of the strategy to be pursued in achieving those goals, accumulated human capital gave experienced entrepreneurs the confidence and credibility to insist upon taking and then implementing crucial decisions. In support of this assertion, we suggest that Firms $H$ and $N$ adopted a pro-active 'competing' approach to conflict resolution; we contend that this approach, rather than collaboration, allowed these entrepreneurs to make positive decisions in the best interests of the firm, VC investors and the wider economy. We thus take issue with the view of Rahim (2002) that a competing/dominating strategy is always a win-lose game in which one party pursues his/her own concerns at the other's expense.

Another important finding was that, in the event of VCs challenging their strategic goals and/or firm performance, both experienced entrepreneurs and start-up players tended to employ the competing approach initially. This contention is tempered with two caveats. First, experienced entrepreneurs were prepared to seek collaboration with their VCs by establishing those areas where skills sets were complementary. Second, and perhaps more significantly, the competing method when pursued by first-time entrepreneurs was not as productive as the 
same approach adopted by experienced entrepreneurs. For example, in the face of conflict over growth aspirations and performance, the entrepreneurs in Firms $K$ and $Y$ had relatively weak bargaining power; this weakness probably stemmed from a combination of factors, including the entrepreneurs' lack of experience, skills deficiencies in certain areas and their perceptions (possibly misplaced) that the VC investors had superior knowledge or power. Nonetheless, these individuals tried to resist the wishes of the VCs, until the founder members eventually concluded that they had no option but to comply with their investors' demands and to leave the firm (i.e. conflict avoidance). We therefore propose that:

Proposition 4a: Entrepreneurs with start-up experience are likely to be effective in managing contractual conflict, by adopting a collaborative or an assertive competing approach.

Proposition 4b: Inexperienced entrepreneurs are likely to have relatively weak bargaining power in the E-VC relationship, and hence pursue a passive accommodating or an avoiding approach to contractual conflict.

The role of human capital in managing contextual conflict was again critical. In sample firms where conflict was avoided, the entrepreneurs established the abilities and motivations of VC investors, discussed potential problem areas in advance and then worked together to neutralize potential disagreements. These entrepreneurs were prepared to acknowledge that VCs offer generic strategic skills that cross continents. We propose that a key component of human capital in China is the ability to accept and act upon external advice, although some firms insisted on retaining control over certain decisions. These approaches to countering contextual conflict helped the sample firms to formulate an appropriate strategic framework, while maximising their ability to survive and prosper in the Chinese market. 
Where contextual conflict did occur, it usually involved disputes between VC investors and first-time entrepreneurs over both strategic and operational issues. These firms were forced to accept advice perceived as culturally misguided and/or inappropriate for the Chinese market. Inexperienced entrepreneurs lacked the capacity to respond to contextual conflict in a positive manner by offering a strong entrepreneurial vision or displaying effective negotiation skills. Hence we propose:

\section{Proposition 5a: Entrepreneurs with start-up experience are likely to be effective in managing contextual conflict, by adopting a collaborative or an assertive competing approach.}

\section{Proposition 5b: Inexperienced entrepreneurs are likely to pursue strategies of passive accommodation or open avoidance in managing contextual conflict.}

In considering the resolution of procedural disputes, it was difficult for the authors to isolate actions undertaken solely in response to procedural conflict; nevertheless, the analysis below sheds important new light on this source of discord. By and large, the greater the human capital possessed by an entrepreneur, the greater the capacity to develop effective communications with VCs. Experienced entrepreneurs recognized the importance of frequent communication with investors (through formal and informal channels), not only to reduce the prospect of misunderstandings but also to increase the scope for the fruitful exchange of ideas. It was also critical to confront any problems quickly. Communication problems were minimised through co-operation and the creation of ample opportunities to explain, exchange, share and discuss operational and strategic issues with the investors.

In contrast, first-time entrepreneurs struggled to establish effective communication systems with their VC investors. Despite the existence of standard communication channels (such as 
quarterly board meetings), these mechanisms served only to generate negativity and mistrust. It is thus no surprise that inexperienced entrepreneurs found it very difficult to resolve procedural conflict. Our study revealed that avoidance tended to be employed more frequently in response to procedural conflict. There was some evidence of accommodation strategies being implemented, but avoidance was the more prevalent reaction, especially where there was acceptance of the status quo and little desire to tackle procedural conflict. Hence we propose:

Proposition 6a: Entrepreneurs with start-up experience are likely to be effective in managing procedural conflict, by adopting collaborative and proactive strategies.

Proposition 6b: Inexperienced entrepreneurs are likely to be ineffective in managing procedural conflict, by pursuing an avoiding approach.

By conducting a systematic and detailed analysis of the E-VC relationship from the perspective of the entrepreneurs, our study contributes to the existing literature in several ways. First, this study complements previous studies conducted from the perspective of VCs. We offer new insights into how the sources of conflict are influenced by the different cultural contexts of entrepreneurs and also their differing characteristics. Second, by adopting a combined conceptual perspective which embraces the literature on human capital and conflict management, we extend previous studies by providing fresh evidence that the human capital of entrepreneurs plays a vital role in shaping the E-VC relationship. By investigating how human capital acquired over time affects entrepreneurial responses to conflict with their VCs, we add a new dimension to studies of entrepreneurial experience.

The findings from the study also have important managerial implications. First, entrepreneurs need to be sensitive towards differences in value systems and in ways of communicating. 
While some studies have found evidence of cultural convergence between the West and China (House et al., 2002), we contend that entrepreneurs need to be equipped with appropriate skills to manage cultural differences in the E-VC relationship and hence to respond to conflict in an effective manner. Second, the findings should raise awareness among entrepreneurs that they can employ a variety of approaches in handling conflict with VCs. Entrepreneurs should be encouraged to adopt a collaborative strategy in the management of procedural conflict; if inexperienced entrepreneurs received training in, for example, communication and negotiation skills, this should enable them to utilise the expertise of the VCs more effectively, as well as increasing their chances of securing VC in future.

\section{CONCLUSION}

Adopting a qualitative analysis, this study examines the sources of conflict between entrepreneurs and VCs, as well as factors affecting conflict resolution. Communication barriers and different value systems are the main sources of conflict between Chinese entrepreneurs and VCs, especially foreign VCs. Our findings show that entrepreneurs with start-up experience are able to manage conflict more constructively in an assertive and cooperative manner, whereas inexperienced entrepreneurs tend to be rather passive, resorting to accommodating and/or avoiding approaches to resolving conflict. Our results show that the approach and attitude of an entrepreneur, mainly shaped by human capital, affect the investee firm's strategic responses to managing conflict; the implication is that individuals with broader pools of human capital and experience should demonstrate greater flexibility and adaptability when managing and resolving conflict. We conclude that a synthesis of the 
literature in the fields of conflict and human capital offers new insights into the E-VC relationship.

\section{REFERENCES}

Ahlstrom, D., Bruton, G., and Yeh, K. (2007). Venture Capital in China: Past, Present, and Future. Asia Pacific Journal of Management, 24(3): 247-68.

Arthurs, J. D. and Busenitz, L. W. (2006). Dynamic Capabilities and Venture Performance: The Effects of Venture Capitalists. Journal of Business Venturing, 21(2): 195-215.

Bosma, N., van Praag, M., Thurik, R., and de Wit, G. (2004). The Value of Human and Social Capital Investments for the Business Performance of Start-Ups. Small Business Economics 23(3): 227-36.

Boulding, K. (1963) Conflict and defense: A general theory, NY: Harper and Brothers. Bruderl, J., Preisendorfer, P., and Ziegler, R. (1992). Survival Chances of Newly Founded Business Organizations. American Sociological Review 57(2): 227-42.

Cai, M. and Song, C. (2010) Chinese VC/PE Industry to Show Modest Growth, Targeting Emerging Industries (Zhong Guo Feng Tou Hang Ye Mu Zi Hui Nuan, Xin Xing Chan Ye Shou Guan Zhu Chinahightech.com, Retrieved :August 2, 2010, http://paper.chinahightech.com.cn/html/2010-11/15/content_20245.htm.)

Chapman, E. and Smith, J. A. (2002). Interpretative Phenomenological Analysis and the New Genetics. Journal of Health Psychology, 7(2): 125-30.

Chen, G., Liu, C., and Tjosvold, D. (2005). Conflict Management for Effective Top Management Teams and Innovation in China. Journal of Management Studies, 42(2): 277300. 
Cooper, N., Estes, C. A., and Allen, L. (2004). Bouncing Back. Parks and Recreation, April (28-35).

Cooper, S. Y. and Lucas, W. A. (2006). Developing Self-Efficacy for Innovation and Entrepreneurship: An Educational Approach. International Journal of Entrepreneurship Education, 4: 141-62.

Cope, J. (2010). Entrepreneurial Learning from Failure: An Interpretative Phenomenological Analysis. Journal of Business Venturing, In Press, Corrected Proof.

Coviello, N. E. and Jones, M. V. (2004). Methodological Issues in International Entrepreneurship Research. Journal of Business Venturing, 19(4): 485-508.

Das, T. L. and Teng, B.S. (1998). Between trust and control: Developing confidence in partner cooperation in alliances. Academy of Management Review, 23(3): 491-512.

De Vries, H. and Shields, M. (2006). Towards a Theory of Entrepreneurial Resilience: An Analysis of New Zealand Sme Owner-Operators. The New Zealand Journal of Applied Business, 5(1): 33-44.

Deutsch, M. (1973). The Resolution of Conflict. New Haven, CT: Yale University Press.

Ehrlich, S. B., De Noble, A. F., Moore, T., and Weaver, R. R. (1994). After the Cash Arrives: A Comparative Study of Venture Capital and Private Investor Involvement in Entrepreneurial Firms. Journal of Business Venturing, 9(1): 67-82.

Envick, B. R. (2005). Beyond Human and Social Capital: The Importance of Positive Psychological Capital for Entrepreneurial Success. The Entrepreneurial Executive, 10: 41-52. Glaser, B. (1978) Theoretical Sensitivity. Sociology Press, Mill Valley: CA.

Hartley, J. F. (1994). Case Studies in Organisational Research.In Cassell, C and G Symon, (Eds.), Qualiative Methods in Organisational Research. London: Sage Publications. 
Higashide, H. and Birley, S. (2002). The Consequences of Conflict between the Venture Capitalist and the Entrepreneurial Team in the United Kingdom from the Perspective of the Venture Capitalist. Journal of Business Venturing, 17(1): 59-81.

House, R., Javidan, M., Hanges, P., and Dorfman, P. (2002). Understanding Cultures and Implicit Leadership Theories across the Globe: An Introduction to Project Globe. Journal of World Business, 37(1): 3-10.

Huff, A. S. (1990). Mapping Strategic Thought Chichester: Wiley.

Jehn, K. and Mannix, E. (2001) The dynamic nature of conflict: A longitudinal study of intragroup conflict and group performance. Academy of Management Journal, 44(2): 238251.

Keong, F. W. F. and Mei, L. Y. (2010). Sustainable Development: The Effect of Adopting Green Technology on Small and Medium Enterprises' (SMEs) Business Resilience and Competitiveness, International conference on business and economic research (ICBER 2010). Kuching Sarawak, Malaysia.

Kor, Y. Y., Mahoney, J. T., and Michael, S. (2007). Resources, Capabilities, and Entrepreneurial Perceptions. Journal of Management Studies 44(7): 1185-210.

Lerner, J., Journal of Business (1999). The Government as Venture Capitalist: The Long-Run Impact of the SBIR Program. Journal of Business, 72(3): 285-318.

McDougall, P. P. and Oviatt, B. M. (2000). International Entrepreneurship: The Intersection of Two Research Paths. Academy of Management Journal, 43(5): 902-08.

Manigart, S. and Sapienza, H. (2000) Venture Capital and Growth, in Sexton, D.L. and Landstrom, H. (eds) The Blackwell Handbook of Entrepreneurship, pp. 240-258, Blackwell Publishers Limited, Oxford, UK.

Miles, M.B. and Huberman, A.M. (1994) Qualitative Data Analysis, Sage Publications, Thousand Oaks: CA. 
Morris, M. H. (2002). Revisiting “Who” Is the Entrepreneur. Journal of Developmental Entrepreneurship Theory and Practice, 7(7): 5-7.

Parhankangas, A. and Landström, H. (2004) Responses to psychological contract violations in the entrepreneur-venture capitalist relationship: An exploratory study. Venture Capital, Pffefer, J. and Salancik, G. (2003) The external control of organizations: A resource dependence perspective, Stanford, CA: Stanford University Press.

Politis, D. (2005). The Process of Entrepreneurial Learning: A Conceptual Framework. Entrepreneurship Theory and Practice, 29(4): 399-424.

Pukthuanthong, K and Walker, T. (2007) Venture Capital in China: a culture shock for Western Investors, Management Decision, 45(4), 708-731.

Rahim, M.(2002). Toward a Theory of Managing Organizational Conflict, International Journal of Conflict Management, 13, 206-235.

Reid, K., Flowers, P., and Larkin, M. (2005). Exploring Lived Experience. The Psychologist, $18(20-23)$.

Shane, S. A. (2008). The Illusions of Entrepreneurship: The Costly Myths That Entrepreneurs, Investors and Policy Makers Live By. New Haven: Yale University Press. Thomas, K. (1976). Conflict and Conflict Management In Dunnette, M, (Ed.), Handbook of Industrial and Organisational Psychology. Chicago: Rand McNally.

Timmons, J. A. (1999). New Venture Creation: Entrepreneurship for the 21st Century (5th Ed). Boston: Irwin.

Tjsovold, D., Law, K., and Sun, H. (2006). Effectiveness of Chinese Teams: The Role of Conflict Types and Conflict Management Approaches. Management and Organization Review 2(2): 231-52. 
Wang, G., Jing, R., and Klossek, A. (2007). Antecedents and Management of Conflict:

Resolution Styles of Chinese Top Managers in Multiple Rounds of Cognitive and Affective Conflict. International Journal of Conflict Management, 18(1): 74-97.

Wright, M., Low, M., and Davidson, P. (2001). Entrepreneurship Research, Progress and Prospects. Entrepreneurship, Theory and Practice 25(4): 5-15.

Wright, M., Pruthi, S., and Lockett, A. (2005). International Venture Capital: From CrossCountry Comparisons to Crossing Countries. International Journal of Management Reviews, 7(3): 135-66.

Xiao, L. (2011). Financing High-Tech Smes in China: A Three Stage Model of Business Development. Entrepreneurship and Regional Development, 23(3-4): 217-34.

Yitshaki, R. (2008). Venture Capitalist-Entrepreneur Conflicts: An Exploratory Study of Determinants and Possible Resolutions. International Journal of Conflict Management, 19(3): 262-92.

Zacharakis, A. L. and Meyer, G. D. (2000). The Potential of Actuarial Decision Models: Can They Improve the Venture Capital Investment Decision? Journal of Business Venturing, 15(4): 323-46.

Zacharakis, A., Erikson, T, and George, B. (2010) Conflict between the VC and entrepreneur: the entrepreneurs’ perspective, Venture Capital, 12(2), 109-126. 
Table 1: Basic Information about the Participants and the Firms

\begin{tabular}{|c|c|c|c|c|c|}
\hline Firm & Industry & Founding Year & Participant & VC & Interview Location \\
\hline D & $\begin{array}{l}\text { Internet audio } \\
\text { video }\end{array}$ & 2005 & CEO & US VC & Beijing \\
\hline $\mathbf{H}$ & Internet 3D & 2005 & CEO & $\begin{array}{l}\text { Japanese VC; Domestic } \\
\text { Group Firm }\end{array}$ & Beijing \\
\hline $\mathbf{K}$ & Internet search & 2006 & CTO & $\begin{array}{l}\text { US VC; Domestic Private } \\
\text { Firm }\end{array}$ & Beijing \\
\hline I & Mobile search & 2005 & CEO & US VC & Shanghai \\
\hline $\mathbf{E}$ & Internet service & 2004 & CEO & US VC & Shanghai \\
\hline $\mathbf{R}$ & DM service & 2001 & CFO & $\begin{array}{l}\text { Japanese VC; Domestic } \\
\text { Private Firm }\end{array}$ & Shanghai \\
\hline $\mathbf{V}$ & Software & 1995 & CEO & US VC; HK Public Firm & Beijing \\
\hline $\mathbf{N}$ & Software & 1994 & $\mathrm{CFO}$ & $\begin{array}{l}\text { Singaporean VC; } \\
\text { Domestic Public Firm; } \\
\text { Domestic State-owned } \\
\text { Firm }\end{array}$ & Shanghai \\
\hline $\mathbf{Y}$ & Robots & 2007 & Deputy GM & Domestic Private Firm & Beijing \\
\hline
\end{tabular}


Table 2: Human Capital of the Interviewed Entrepreneurs

\begin{tabular}{|c|c|c|}
\hline Firm & Experience & Network \\
\hline D & First-time entrepreneur & $\begin{array}{l}\text { Former classmates form the founding team; } \\
\text { limited networks }\end{array}$ \\
\hline $\mathbf{H}$ & $\begin{array}{l}\text { 90s: Manager of an Internet firm; } \\
\text { 00s: Started an online book firm }\end{array}$ & $\begin{array}{l}\text { Well-known in internet sector; connections } \\
\text { with VC community; friends from previous } \\
\text { internet ventures form the founding team; }\end{array}$ \\
\hline $\mathbf{K}$ & First-time entrepreneur & $\begin{array}{l}\text { Classmates form the founding team; limited } \\
\text { network involvement }\end{array}$ \\
\hline $\mathbf{I}$ & $\begin{array}{l}\text { Over } 15 \text { years management } \\
\text { experience in high-tech industry, } \\
\text { including } 9 \text { years in Great China } \\
\text { region; } \\
\text { Worked for a large MNE in 90s } \\
\text { when it established a subsidiary in } \\
\text { Shanghai; } \\
\text { Started two firms in US in 00s }\end{array}$ & $\begin{array}{l}\text { Previous colleague at the MNEs form the } \\
\text { founding team; good connections with US } \\
\text { VC community }\end{array}$ \\
\hline $\mathbf{E}$ & First-time entrepreneur & Some connections with US VC community \\
\hline $\mathbf{R}$ & $\begin{array}{l}\text { Worked for a large domestic firm in } \\
\text { 90s in message servicing sector. } \\
\text { Started up business in customer } \\
\text { databases in late } 90 \text { s. }\end{array}$ & $\begin{array}{l}\text { Previous contact with VCs; Leading firm } \\
\text { position in the industry }\end{array}$ \\
\hline
\end{tabular}

\begin{tabular}{lll}
$\mathbf{V}$ & $\begin{array}{l}\text { Worked for a large domestic firm in } \\
\text { 90s in software industry; }\end{array}$ & $\begin{array}{l}\text { Well-known in software industry; good } \\
\text { connections with VC community; contacts } \\
\text { with previous colleagues, classmates and } \\
\text { other players in the industry, both in China } \\
\text { and the US }\end{array}$ \\
$\mathbf{N}$ & $\begin{array}{l}\text { 90s started up first business in IT } \\
\text { equipment. } \\
\text { 00s started up firm in software } \\
\text { industry }\end{array}$ & $\begin{array}{l}\text { Leading firm position in the market; } \\
\text { previous contacts with VCs }\end{array}$ \\
\hline $\mathbf{Y}$ & First-time entrepreneur & Some domestic networks and contacts \\
\hline
\end{tabular}


